\title{
Measuring the effectiveness of Poland's fire monitoring system
}

\author{
J. Piwnicki, B. Ubysz \& R. Szczygieł \\ Independent Forest Fire Protection Laboratory, \\ Forest Research Institute, Poland
}

\begin{abstract}
Between 2002 and 2006, the state-owned forest fire observation system detected approximately $56 \%$ of all Polish wildfires. The remaining $44 \%$ were detected by civilians. From this we can conclude that when a wildfire is detected, public reaction time is very rapid. The observation system in the National Forests can be regarded as comprehensive, covering the forest areas that have been classified as having a high and medium wildfire risk potential. The average size of all wildfires on Polish National Forests for the period 2002 to 2006 of 0.36 ha demonstrates the effectiveness of the current detection system. Outside of the Polish National Forests the figure jumps to 1.03 ha on average for the same period. This indicates a significant delay in reporting and responding to these fires because they are not protected by an organized wildfire detection system. No wildfire detection system is required in Poland, if the forest area is less than 300 ha (privately-owned forests of this size are the most common in Poland). In addition, there are no effective motivating programs for the private forest landowners that would plan, design and implement a wildfire detection system. The reason for this is simple; these forests do not offer any significant economic value because of their size. It should be added that farmers (who are the predominant owners of private forests) have forests that average approximately $1 \mathrm{ha}$. However, when you look at the entire area, they make up a larger block that is frequently threatened by wildfire. Unfortunately the local communities do not have the funds to implement a wildfire detection system.
\end{abstract}

Keywords: forest fire detection, wildfire, lookout towers, forest fire danger. 


\section{Legal framework}

Polish wildfire detection is regulated by a decree from the office of the Minister of the Environment dated March 22 ${ }^{\text {nd }}, 2006$. This decree deals with special wildfire protection principles (Journal of Laws, issue 58, item 405). In accordance with this decree, if a forested area exceeds 300 ha, and it has been determined that the wildfire risk is high or medium (wildfire danger classes I or II), on days where the danger from wildfires has been determined to be 1., 2. or 3. (determined on the basis of a daily forecast for these areas), it then becomes necessary to conduct wildfire detection so that fires can be detected early, reported early, and immediate suppression action can be taken.

\section{Fire monitoring system}

Poland's wildfire detection system is comprised of:

- a network of fire lookout towers,

- ground patrols,

- air patrols.

\subsection{Fire tower network}

The construction of fire towers in the Polish network is such that it allows for direct or indirect observation/detection of the surrounding area so that when a wildfire is detected it can be reported immediately to the appropriate responders. Depending on circumstance and wildfire danger, other facilities are also incorporated into the network e.g., triangulation towers, water towers or church steeples.

The selection of the most appropriate location for a fire tower is based on maximizing the viewable area; the size of the viewable area is measured by the observation/visibility radius. Normally, we assume this measurement to be between 10 and $15 \mathrm{~km}$. This measurement is critical when designing the entire network and determining the total number of necessary tower sites. One important limiting factor that must be considered, especially in urban/industrial areas is air quality, a reduction factor should be applied to these areas. The same consideration should be given to areas with uneven topography.

As of December $31^{\text {st }}, 2006$ the Polish national fixed fire tower network (at present there are no fixed fire towers for wildfire detection on other lands) consisted of 637 sites, these included: 479 metal, 112 brick, 38 wooden and 8 other.

A review of the number and density/10,000 ha of fire towers by National Forest directorates is shown in table 1 . The greatest numbers of fire towers can be found in Zielona Góra's (67), Katowice's (65) and Szczecin's (56) RDSF, which have the highest (first category) wildfire risk classification while the lowest numbers are in Kraków's (5) and Krosno's (14) RDSFs, which are made up of mostly upland/highland areas, these have the lowest wildfire risk (third category). 
Table 1: The number of fire towers by RDSF and their density (as of $31^{\text {st }}$ December, 2007).

\begin{tabular}{|r|l|c|c|c|c|}
\hline No. & \multicolumn{1}{|c|}{ RDSF } & FFDC $^{*}$ & Forest area [ha] & Total & $\begin{array}{c}\text { No of towers per } \\
10,000 \text { ha }\end{array}$ \\
\hline 1. & Białystok & 2 & 569,300 & 37 & 0.65 \\
\hline 2. & Gdańsk & 2 & 283,100 & 30 & 1.06 \\
\hline 3. & Katowice & 1 & 592,600 & 65 & 1.10 \\
\hline 4. & Kraków & 3 & 167,500 & 5 & 0.30 \\
\hline 5. & Krosno & 3 & 398,000 & 14 & 0.35 \\
\hline 6. & Lublin & 2 & 391,400 & 33 & 0.84 \\
\hline 7. & Łódź & 2 & 282,000 & 22 & 0.78 \\
\hline 8. & Olsztyn & 2 & 563,000 & 29 & 0.52 \\
\hline 9. & Piła & 1 & 337,200 & 27 & 0.80 \\
\hline 10. & Poznań & 1 & 406,400 & 32 & 0.79 \\
\hline 11. & Radom & 2 & 308,300 & 43 & 1.39 \\
\hline 12. & Szczecin & 1 & 634,000 & 56 & 0.88 \\
\hline 13. & Szczecinek & 2 & 563,800 & 50 & 0.89 \\
\hline 14. & Toruń & 1 & 420,600 & 52 & 1.24 \\
\hline 15. & Warszawa & 1 & 180,900 & 38 & 2.10 \\
\hline 16. & Wrocław & 1 & 522,000 & 37 & 0.71 \\
\hline 17. & Zielona Góra & 1 & 422,600 & 67 & 1.59 \\
\hline & Total in Poland & $7,042,700$ & 637 & 0.90 \\
\hline
\end{tabular}

${ }^{*}$ Forest fire danger class.

The average fire tower density per 10,000 ha of forest area in Poland is 0.9. The greatest density of fire towers can be found in the RDSFs of Warsaw (2.1), Zielona Góra (1.59), Radom (1.39) and Torun (1.24). The density coefficient of fire towers is significantly below the national average in the RDSFs in Kraków (0.30), Krosno (0.35), Olsztyn (0.52) and Białystok (0.65).

\subsection{Ground patrols}

The fire tower and aircraft detection apparatus are supplemented by ground patrols in the Polish system. Ground patrols are organized by national forest/parks. This part of the fire detection system is most effective in those areas of greatest wildfire risk, in areas where we have considerable tourist traffic, along busy transportation routes and in those areas where no other wildfire detection is available. The use of ground patrols is implemented at the lowest (third category) of wildfire risk. Operational decisions like their use, patrol areas and routs are handled by the local national forests/parks.

Suppression action begins immediately once a ground patrol detects a wildfire. If the wildfire is beyond their capability to handle, they are to notify the local alarm post. Although the ground patrol is less effective than the fire tower network, there is a psychological advantage to their presence. The public 
knows they are there and that they are paying attention to visitors and their actions on the national forest. The end result is that the public tend to adhere more rigorously to posted regulations governing national forest use.

The number of ground patrols on National Forest between 2002 and 2006 is described in Table 2. The total number of patrols for the period was 14,049. Forest areas of Gdańsk's $(2,812)$, Lublin's $(2,441)$ and Olsztyn's $(2,199)$ RDSFs had the most frequent patrols, while in Poznan they were patrolled the least (57 times).

Table 2: $\quad$ Number of ground patrols by RDSF between 2002 and 2006.

\begin{tabular}{|r|l|r|r|r|r|r|r|}
\hline No & \multicolumn{1}{|c|}{ RDSF } & FFDC & 2002 & 2003 & 2004 & 2005 & 2006 \\
\hline 1. & Białystok & 2 & 81 & 53 & 53 & 6 & 44 \\
\hline 2. & Gdańsk & 2 & 517 & 491 & 466 & 760 & 578 \\
\hline 3. & Katowice & 1 & 70 & 61 & 62 & 19 & 171 \\
\hline 4. & Kraków & 3 & 113 & 129 & 104 & 121 & 18 \\
\hline 5. & Krosno & 3 & 182 & 141 & 119 & 249 & 354 \\
\hline 6. & Lublin & 2 & 161 & 176 & 148 & 213 & 1,743 \\
\hline 7. & Lódź & 2 & 134 & 112 & 114 & 107 & 94 \\
\hline 8. & Olsztyn & 2 & 775 & 467 & 266 & 197 & 494 \\
\hline 9. & Piła & 1 & 22 & 43 & 62 & 28 & 50 \\
\hline 10. & Poznań & 2 & 101 & 64 & 52 & 50 & 13 \\
\hline 11. & Radom & 1 & 71 & 73 & 56 & 17 & 24 \\
\hline 12. & Szczecin & 2 & 39 & 164 & 36 & 25 & 46 \\
\hline 13. & Szczecinek & 1 & 93 & 95 & 104 & 66 & 128 \\
\hline 14. & Toruń & 1 & 4 & 8 & 16 & 11 & 4 \\
\hline 15. & Warszawa & 1 & 305 & 121 & 136 & 634 & 427 \\
\hline 16. & Wrocław & 1 & 48 & 92 & 85 & 12 & 17 \\
\hline 17. & Zielona Góra & & 2,725 & 2,311 & 1,893 & 2,520 & 4,213 \\
\hline
\end{tabular}

\subsection{Air patrols and detection}

Although the use of air patrols to detect wildfires began as early as the 1970's it did not really become practical until the late 1980's. This method of wildfire detection is extremely effective because of the large area they can cover (due to the altitude and speed of the plane), and their ability to get directly over a wildfire if it is detected, do the critical "size up" of the situation and lead suppression crews in to the wildfire location. In order to maximize the effectiveness of the aircraft the entire patrol route should not take more than 45 min. This allows the plane to quickly double back over their route, even if their current position is very unfavourable, and detect a wild fire during its initial propagation phase. 
Table 3 shows the number of aircraft used for patrolling the Polish National Forests between 2002 and 2006.

Wildfire detection was managed by 10 aircraft (12 at most) along 31 permanently planned routs; the average patrolling time was 2.5 hours. Aircraft were not used in the RDSFs of Gdańsk, Kraków, Lublin, Łódź and Szczecinek. The primary disadvantage of wildfire detection with aircraft is the cost. To cut down on the costs the system incorporates light aircraft to maximize economy. In spite of the effort to reduce costs to a minimum, the use of aircraft for wildfire detection has decreased over the past few years. They are used only when the risk from wildfire is very high and other types of wildfire detection are not available. Our view is that aircraft should supplement/augment the ground apparatus.

Table 3: $\quad$ Number of patrol aircrafts by RDSF between 2002 and 2006.

\begin{tabular}{|r|l|c|c|c|c|c|c|}
\hline No. & RDSF & FFDC & 2002 & 2003 & 2004 & 2005 & 2006 \\
\hline 1. & Białystok & 2 & 1 & 0 & 0 & 0 & 0 \\
\hline 2. & Gdańsk & 2 & 0 & 0 & 0 & 0 & 0 \\
\hline 3. & Katowice & 1 & 1 & 1 & 0 & 0 & 0 \\
\hline 4. & Krosno & 3 & 1 & 1 & 0 & 1 & 1 \\
\hline 5. & Kraków & 3 & 0 & 0 & 0 & 0 & 0 \\
\hline 6. & Lublin & 2 & 0 & 0 & 0 & 0 & 0 \\
\hline 7. & Lódź & 2 & 0 & 0 & 0 & 0 & 0 \\
\hline 8. & Olsztyn & 2 & 1 & 1 & 1 & 1 & 1 \\
\hline 9. & Piła & 1 & 1 & 1 & 1 & 1 & 1 \\
\hline 10. & Poznań & 1 & 0 & 1 & 1 & 0 & 0 \\
\hline 11. & Radom & 2 & 1 & 0 & 0 & 0 & 0 \\
\hline 12. & Szczecin & 1 & 2 & 2 & 2 & 2 & 2 \\
\hline 13. & Szczecinek & 2 & 0 & 0 & 0 & 0 & 0 \\
\hline 14. & Toruń & 1 & 0 & 1 & 1 & 1 & 1 \\
\hline 15. & Warszawa & 1 & 2 & 2 & 2 & 2 & 2 \\
\hline 16. & Wrocław & 1 & 1 & 1 & 1 & 1 & 1 \\
\hline 17. & Zielona Góra & 1 & 1 & 0 & 1 & 1 & 1 \\
\hline & Total in Poland & 12 & 11 & 10 & 10 & 10 \\
\hline
\end{tabular}

\section{The effectiveness of Poland's existing wildfire observation system}

Table 4 described how effective Poland's wildfire detection system was between 2002 and 2006 on our National Forests. 24,641 wildfires were detected on Poland's national forests during that period. Of the three separate elements comprising the wildfire detection system, the fixed fire towers were the most effective with $37 \%$ of the total wildfires detected. $17 \%$ were detected by ground patrols and the least, $2.5 \%$ were detected by aircraft. The greatest number of wildfires was reported by the general public, who in large measure thanks to a 
well developed communications system (primarily cellular phones) reported almost $44 \%$ of all wildfires. We should note here that only the first "reported by" is logged on the fire report, any subsequent notifications of detection will not be logged. These reports are generally used to confirm the wildfire, and sources of more precise information and size up of the wildfire and its location.

Table 4: $\quad$ Forest fire detection effectiveness by type in each RDSF for the period 2002-2006 (in \%).

\begin{tabular}{|c|c|c|c|c|c|c|c|}
\hline No. & RDSF & FFDC & $\begin{array}{c}\text { Number } \\
\text { of fires }\end{array}$ & $\begin{array}{c}\text { Lookout } \\
\text { towers }\end{array}$ & $\begin{array}{c}\text { Air } \\
\text { patrols }\end{array}$ & $\begin{array}{l}\text { Ground } \\
\text { patrols }\end{array}$ & Civilians \\
\hline 1. & Białystok & 2 & 900 & 34.11 & 1.22 & 18.22 & 46.45 \\
\hline 2. & Gdańsk & 2 & 475 & 24.00 & 0.21 & 17.89 & 57.90 \\
\hline 3. & Katowice & 1 & 3,200 & 32.03 & 2.53 & 18.91 & 46.53 \\
\hline 4. & Kraków & 3 & 101 & 4.95 & 0.00 & 48.52 & 46.53 \\
\hline 5. & Krosno & 3 & 151 & 14.57 & 3.31 & 21.85 & 60.27 \\
\hline 6. & Lublin & 2 & 620 & 18.06 & 0.97 & 26.13 & 54.84 \\
\hline 7. & Łódź & 2 & 1,363 & 16.73 & 0.22 & 17.61 & 65.44 \\
\hline 8. & Olsztyn & 2 & 1,018 & 15.72 & 2.65 & 16.99 & 64.64 \\
\hline 9. & Piła & 1 & 620 & 41.94 & 1.94 & 11.77 & 44.35 \\
\hline 10. & Poznań & 1 & 1,600 & 23.31 & 1.19 & 11.75 & 63.75 \\
\hline 11. & Radom & 2 & 1,728 & 48.03 & 1.68 & 20.26 & 30.03 \\
\hline 12. & Szczecin & 1 & 2,472 & 32.97 & 7.16 & 18.97 & 40.90 \\
\hline 13. & Szczecinek & 2 & 657 & 32.72 & 1.83 & 18.42 & 47.03 \\
\hline 14. & Toruń & 1 & 1,776 & 43.41 & 1.35 & 6.36 & 48.88 \\
\hline 15. & Warszawa & 1 & 1,684 & 38.95 & 7.30 & 20.67 & 33.08 \\
\hline 16. & Wrocław & 1 & 2,106 & 30.63 & 2.23 & 26.87 & 40.27 \\
\hline 17. & Zielona G. & 1 & 4,170 & 61.53 & 0.77 & 9.14 & 28.56 \\
\hline \multicolumn{3}{|c|}{ Total / average } & 24,641 & 36.95 & 2.47 & 16.72 & 43.86 \\
\hline
\end{tabular}

\section{References}

[1] Piwnicki, J., Szczygieł, R., Ubysz, B. \& Kwiatkowski, M., Economic analysis of the functioning of the forest fire protection system in Poland. Abstracts of the $5^{\text {th }}$ international conference on Forest Fire Research, ed. D.X. Viegas, ADAI, University of Coimbra, Portugal, p. 209, 2006.

[2] Piwnicki, J., Szczygieł, R. \& Ubysz, B., Economic analysis of functioning of the forest fire protection in the State Forests National Forest Holding (with the division into obligatory and additional tasks). Forest Research Institute, Warsaw, 2005. 
[3] Analysis of the state of the forest fire protection in the State Forests National Forest Holding in 2004. General Directorate of the State Forests, Warsaw, PL.

[4] Analysis of the state of the forest fire protection in the State Forests National Forest Holding in 2005. General Directorate of the State Forests, Warsaw, PL.

[5] Analysis of the state of the forest fire protection in the State Forests National Forest Holding in 2006. General Directorate of the State Forests, Warsaw, PL. 